\title{
PHYSICO-CHEMICAL CHARACTERIZATION OF GROUNDWATER OF KALTUNGO, GOMBE STATE, NIGERIA AND TREATMENT FOR FLOURIDE REMOVAL
}

\author{
S. B. Onoja ${ }^{1,}{ }^{*}$, M. 0. Isikwue ${ }^{2}$ and J. F. Malum ${ }^{3}$ \\ 1,2,3 Dept. of Agric. \& Environmental EngineEring, Univ. of Agriculture, MaKuRdi, BenUe State. NigERIA \\ E-mail addresses: ${ }^{1}$ samomyonoja@yahoo.com, 2 okeyisikwue@gamil.com,3 jmflayin@gmail.com
}

\begin{abstract}
Physico-chemical characteristics of Kaltungo groundwater were determined for a period of 12 months. The physical characteristics include odour, colour, taste, temperature, turbidity and TDS; while conductivity, pH, chloride, iron, copper, lead, zinc, fluoride, cadmium, nitrates, TH, total alkalinity (TA) and fluoride were the chemical characteristics. Nine water samples, three from three hand dug wells and six from six boreholes were taken monthly for the period. This study was undertaken because the people of Kaltungo town depend on groundwater from hand dug wells and boreholes for their water needs and children who grow up in the town during the ages of teething end up having mottled teeth. The results showed that the physical parameters were below their maximum limits, except temperature that had a mean of $29.7^{\circ} \mathrm{C}$, which was still within ambient temperature. Most of the chemical parameters were below the recommended maximum limits except Iron and fluoride which had mean monthly values of $0.9 \mathrm{mg} / \mathrm{l}$ and $1.66 \mathrm{mg} / \mathrm{l}$ as against $0.3 \mathrm{mg} / \mathrm{l}$ and $1.5 \mathrm{mg} / 1$ respectively. Treatments for flouride removal carried out with alum, bone charcoal and Moringa olifera seeds showed that fluoride concentrations in water was reduced when treated with dosages $\geq 10 \mathrm{~g} / \mathrm{l}$ of raw water by between $15 \%$ and 43\% reduction. Kaltungo groundwater should be treated for fluoride removal before consumption to avert teeth mottling.
\end{abstract}

Keywords: Characteristics, fluoride, groundwater, teeth mottling, treatment

\section{INTRODUCTION}

Water is one of the most important natural resources. It is vital for all living organisms' metabolic processes as well as for human health, food production and socioeconomic development, assisting local commerce and industry [1]. The source of all water over the earth is precipitation. When rain falls, some flow on the ground surface to streams or lakes, some infiltrate into the ground and are used by plants and some percolate to contribute to groundwater while some evaporate to the atmosphere [2].

Groundwater is the water that is found underground in the soil formation where all the soil pores are filled with water [3]. Groundwater that can be sources of water to harness are called aquifers, which are soil formations that both contain water and can significantly transmit water [4]. Groundwater is the earth's largest store of water, estimated to account for $94 \%$ of all water. It constitutes about two-thirds of the fresh water reserves of the world [5]. An unconfined aquifer is bounded on the top by a water table which may be deep or shallow and may rise or fall depending on the prevailing climatic factors. Heavy rains or melting snow may cause the water table to rise while heavy pumping of the groundwater supplies may cause the water table to fall. Groundwater in aquifers can discharge into lakes and streams. It can also be extracted through hand dug wells or drilled wells (boreholes) into the aquifer.

Studies of the quality of groundwater are important in determining the usefulness of groundwater for various purposes [5, 6]. Though the soil as a known natural filter is capable of purifying surface water that passes through it to the groundwater, the capacity of soil and rock to remove pollutants from groundwater varies widely from one area to another. There are other reasons why groundwater can be contaminated and become impure especially for human consumption. The quality of groundwater depends on the soil characteristics, geology, hydrogeology, hydrology, the nature of the contaminants and urbanization $[5,7]$

The physical and chemical characteristics of water determine the quality of water in a particular area. Some may have harmful effects on the people who use the water for drinking. The concentration of harmful total dissolved materials in raw sewage water is similar to that found in many groundwater supplies used as drinking water [8] and [9]. 


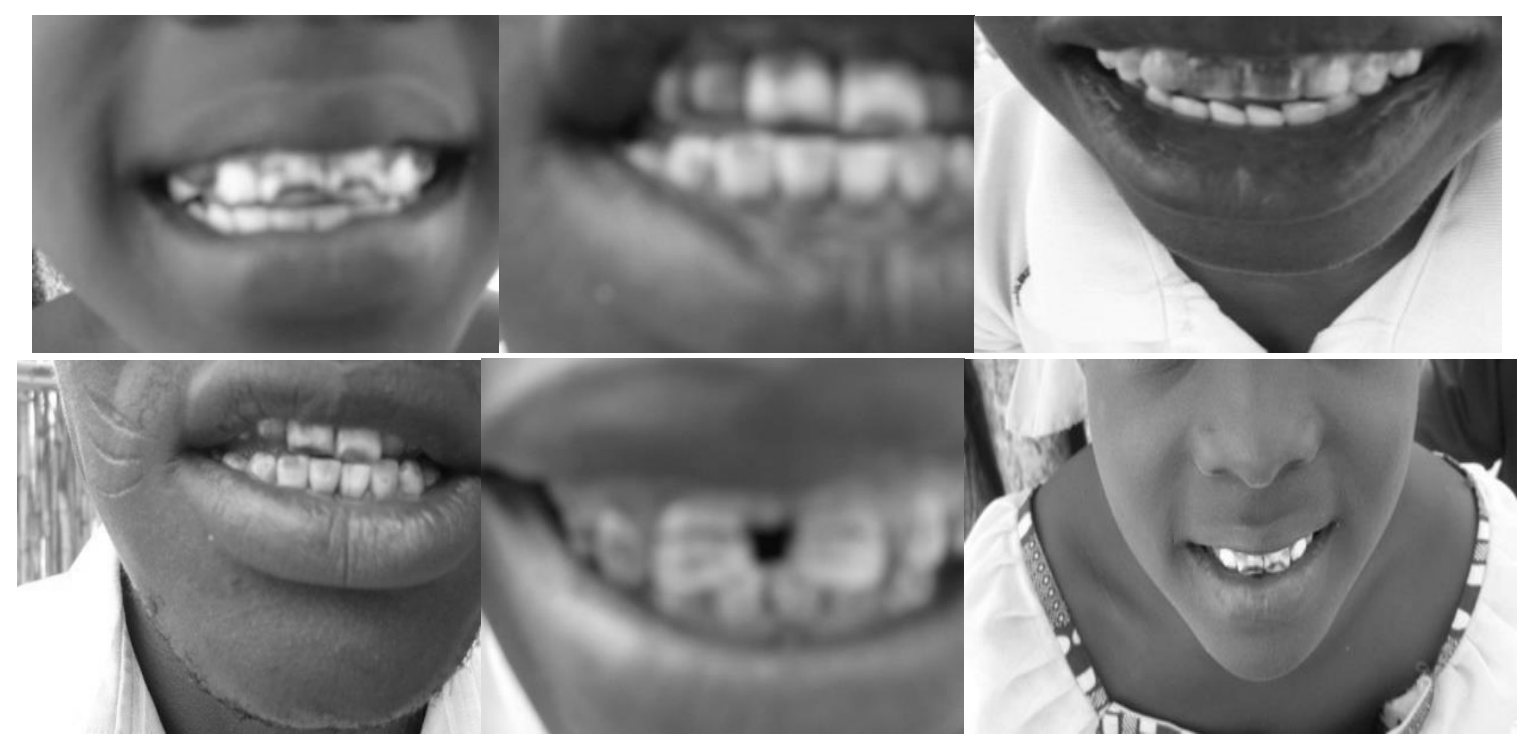

Plate 1 Samples of mottled teeth, Source: Field Survey, 2011

Water supply to certain semi urban and rural areas in Nigeria is dependent on the exploitation of groundwater $[10 ; 11]$ and this is estimated to serve about $21 \%$ of the population [12]. In Kaltungo town, the headquarters of Kaltungo Local Government Area of Gombe State Nigeria, the residents depend largely on groundwater as the primary source of domestic water. It has been noticed that children between the age of teething and thirteen years in Kaltungo town grow up with brown mottled (stained) teeth (Plate 1).

This is called fluorosis and the critical period is between ages one and four during tooth development with the risk ending around age eight [13], but those who come into the town after this age bracket do not develop mottled teeth. It was suspected that the brown mottling of teeth might have been caused by the chemical quality of the town's sources of drinking water which is mainly groundwater. Mottling of teeth can be caused by high fluoride concentration in drinking water through fluoridated water or through toothpastes [14].

The objectives of this study were to determine the suitability of water in Kaltungo town for drinking and whether the concentration of fluoride was high enough to cause mottling of teeth as well as proffer solutions to the problem.

\section{MATERIALS AND METHODS}

\subsection{Study Area}

Kaltungo town is the headquarters of Kaltungo Local Government Area, of Gombe State, Nigeria. Fig.1shows the map of Gombe State and Fig. 2 Kaltungo town. It is located on Latitude $09^{\circ} 48^{\prime} 54^{\prime \prime} \mathrm{N}$ and Longitude $11^{0} 18^{\prime}$ 24" E, with a land area of about $121.8 \mathrm{sq} \mathrm{Km}$, and a population of over 300,000 people [15]. The average annual rainfall is $1000 \mathrm{~mm}$ and falls within a very short time of 3-4 months in a year.

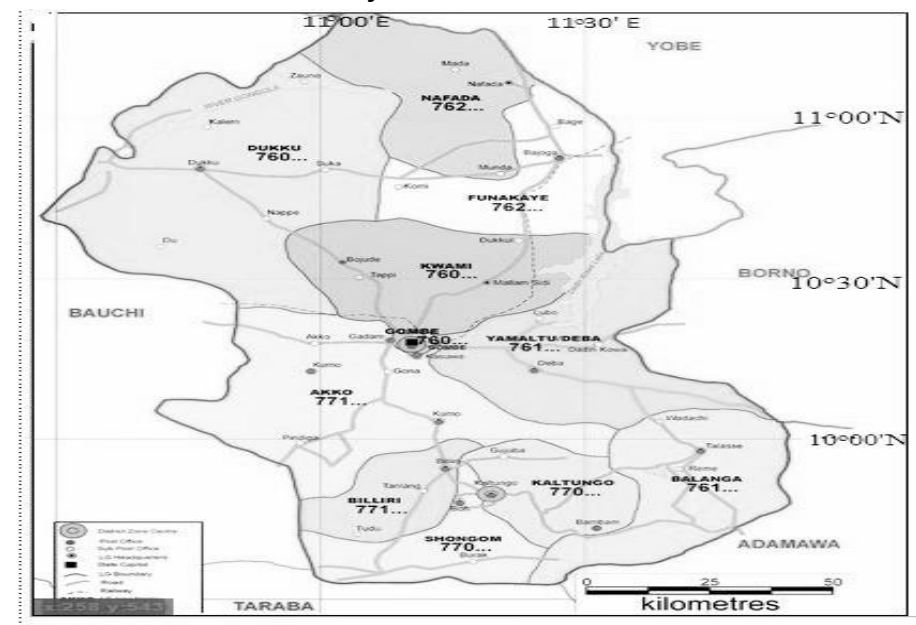

Fig. 1 Map of Gombe State showing the Local Government Areas

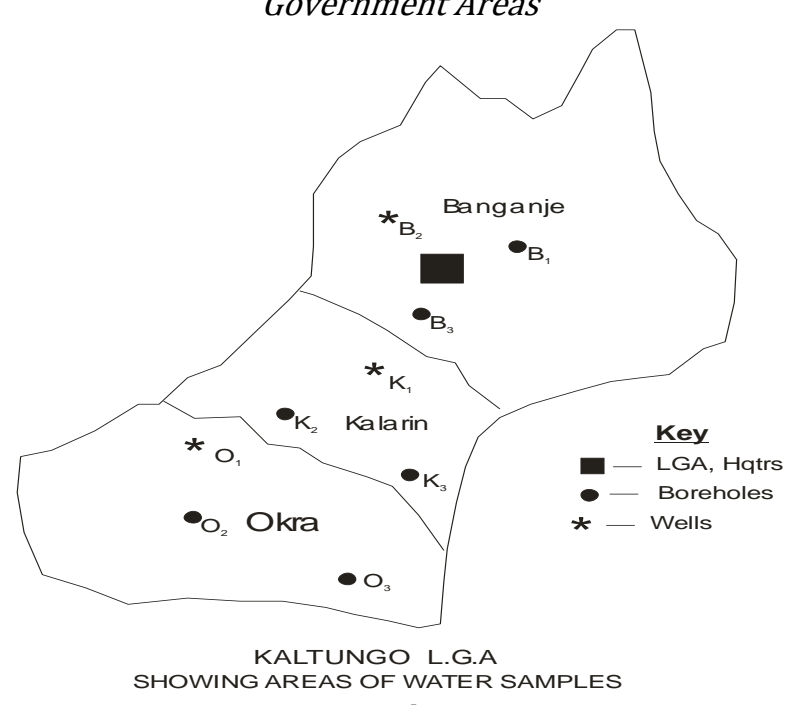

Fig 2 Sampling Points 
Gombe State, Nigeria, and its surroundings are situated on the basement complex of Nigeria which is made up of crystalline rocks $[16 ; 17]$. The basement complex consists of bauxite, granite, diorite, magmatites and gneiss [18; 19]. Fractured and weathered crystalline rocks were identified as the common water aquifers in Kaltungo area [16]. The fractured crystalline rocks were encountered in boreholes and hand dug wells at various depths [20]. In Kaltungo town, the area was divided into 3 sub areas as follows: Baganje - Area B, with sampling points at $\left(B_{1}, B_{2}, B_{3}\right)$, Kalarin Area $K$, with sampling points at $\left(\mathrm{K}_{1}, \mathrm{~K}_{2}, \mathrm{~K}_{3}\right)$ and Okra - Area $\mathrm{O}$, with sampling points $\operatorname{at}\left(\mathrm{O}_{1}, \mathrm{O}_{2}, \mathrm{O}_{3}\right)$. (Fig. 2)

\subsection{Sample Collection and Analysis}

Water samples were collected from 9 sources (3 hand dug wells (HDW) and 6 boreholes (BH). One sample was collected from each sampling point monthly for twelve months. The sampling from wells was done by drawing water manually, and pouring into 1litre plastic bottles. Samples from boreholes were taken after steady flow of water from the boreholes was reached which took about 2 minutes to clear the water line according to Ademoroti [21]. All the samples were properly covered and transported immediately in a cooler to the laboratory for analysis. The water samples were analyzed at Quality
Control Laboratory of Gombe State Water Corporation Gombe and Northeast Regional Water Quality Laboratory of Federal Ministry of Water Resources, Gombe, Nigeria. Physical characteristics determined according to standard methods[22] include odour, colour, taste, temperature, turbidity and total dissolved solids (TDS) while chemical parameters were $\mathrm{pH}$, conductivity, chloride, iron, copper, lead, zinc, fluoride, cadmium, nitrates, total hardness (TH) and total alkalinity (TA). Table 1 shows the standard methods used and the equipment used.

\subsection{Water Treatment}

Three readily available materials, aluminum silicate, $\mathrm{Al}_{2}$ $\left(\mathrm{SO}_{4}\right)_{3}$ (alum), animal bone charcoal and moringaoleifera seeds, known to have been used for water treatment before [23 - 25] were used to treat water samples to see whether they could reduce the concentration of fluoride in the water. The choice to remove fluoride was because flouride concentration was found to be higher than the desired limit of $1.5 \mathrm{mg} / \mathrm{l}$ throughout the study period. Flouride concentration greater than $1,5 \mathrm{mg} / \mathrm{l}$ can cause mottling of teeth. Three water samples (untreated) were taken from a source known to have high concentrations of fluoride and examined.

Table 1: Methods and instruments used for the determination of the Physico-chemical characteristics

\begin{tabular}{|c|c|c|c|c|}
\hline $\mathrm{S} / \mathrm{n}$ & Characteristics & Units & $\begin{array}{l}\text { Methods of } \\
\text { analysis }\end{array}$ & Instruments used \\
\hline 1. & Odour & - & Perceive & Water glass bottle, Human nostrils \\
\hline 2. & Colour & TCU & Laboratory & Lovibond colour disc \\
\hline 3. & Taste & - & Mouth taste & Water glass, Human mouth \\
\hline 4. & Temperature & $0^{\circ} \mathrm{C}$ & Probe Meter & Glass bulb Thermometer \\
\hline 5. & Turbidity & NTU & Laboratory & Turbidimeter, Current source \\
\hline 6. & Total dissolved soilds & $\mathrm{mg} / \mathrm{l}$ & Gravimetric & Oven, petri dish \\
\hline 7. & $\mathrm{Ph}$ & & Electrometric & pH metre, \\
\hline 8. & Iron $(\mathrm{Fe})$ & $\mathrm{mg} / \mathrm{l}$ & Colorimetry & $\begin{array}{l}\text { Atomic Absorption Spectro- } \\
\text { photometry (AAS), }\end{array}$ \\
\hline 9. & Copper $(\mathrm{Cu})$ & $"$ & Colorimetry & " \\
\hline 10 & Lead $(\mathrm{Pb})$ & $\mu \mathrm{g} / \mathrm{l}$ & Colorimetry & $“$ \\
\hline 11. & Zinc (Zn) & $\mathrm{mg} / \mathrm{l}$ & Colorimetry & “ \\
\hline 12. & Cadmium (Cd) & $\mathrm{mg} / \mathrm{l}$ & Colorimetry & “ \\
\hline 13. & Chlorine (Cl) & $\mathrm{mg} / \mathrm{l}$ & Titration & Reagents and Lab Equipment \\
\hline 14. & Fluoride $(\mathrm{F})$ & $\mathrm{mg} / \mathrm{l}$ & Colorimetry & Flame Photometer \\
\hline 15. & Nitrate $\left(\mathrm{NO}_{3}\right)$ & $\mathrm{mg} / \mathrm{l}$ & Titration & Reagents and Lab Equipment \\
\hline 16. & Total Hardness (TH) & $\mathrm{mg} / \mathrm{l}$ & Titration & Reagents and Lab Equipment \\
\hline 17. & Total Alkanity (TA) & $\mathrm{mg} / \mathrm{l}$ & Titration & Reagents and Lab Equipment \\
\hline 18. & Conductivity & $\mu \mathrm{S} / \mathrm{cm}$ & Colorimetry & Conductivity meter \\
\hline
\end{tabular}


The results showed concentrations above the maximum limit. The samples were thereafter treated with alum, bone charcoal and moringaoleifera seeds. Four levels of $5 \mathrm{~g}, 10 \mathrm{~g}, 15 \mathrm{~g}$ and $20 \mathrm{~g}$ of each material were taken after crushing (where need be for bone charcoal and moringaoleifera) and added to 1 litre of untreated water samples of known fluoride concentration (i.e. each level of treatment material was added to 1 litre of untreated water). Each level of treatment was replicated three times. Each treated sample was kept for 24 hours after treatment. After 24 hours, the treated water was sieved to remove the residues and the filtrate analyzed in the laboratory for fluoride concentrations.

\section{RESULTS AND DISCUSSION}

\subsection{Physical Characteristics}

Monthly mean concentrations of physical parameters of water from HDW are shown in Table 2 while those for $\mathrm{BH}$ are shown in Table 3 . The monthly mean results of odour, colour and taste from both the HDW and $\mathrm{BH}$ indicated that, the water samples had no odour; no colour and no offensive taste. This was the case throughout the year of study, indicating no seasonal variation. It also indicates that the waters from the HDW and $\mathrm{BH}$ were from depths that rainfall runoff and infiltration could not affect the odour, colour and taste. So they are very acceptable for drinking all year round on these notes..
The temperatures of samples from both HDW and $\mathrm{BH}$ compared favourably with each other with a mean result of $29.7^{\circ} \mathrm{C}$ each. This also compared well with the ambient temperatures of Kaltungo town taken for six months (July - December), with a mean of 30 o C.BH temperatures had a mean value of $29.7{ }^{\circ} \mathrm{C}$, which is higher than WHO [26,]guideline of $25^{\circ} \mathrm{C}$, but acceptable by NIS,SON/NAFDAC [27,]which puts a limit of ambient temperature.. The high mean temperature of Kaltungo town, Gombe State is obvious because it is in the northern part of Nigeria that is usually hot and dry. Kaltungo town is surrounded by mountainous crystalline rocks which have high heat retention capacity. The high water temperature could be attributed to heat transfer between water and the land body [27].The water temperature was virtually constant through the year.

The turbidity of water samples from HDW and $\mathrm{BH}$, showed a monthly mean results of 1.9 NTU (Table 2) and 0.9 NTU (Table 3) respectively. Turbidities of HDW and of BH followed similar trend throughout the period of the study. The mean results were about twice higher for HDW than those for BH for most of the months of study. Turbidity results showed that all the samples had mean concentrations below maximum limit of 5 NTU by WHO and NIS/SON/ NAFDAC [27]. (Table 3). This is expected because, Kaltungo town is known to be dominated by crystalline basement formations of igneous, metamorphic rocks and sandy soils devoid of clayey and loamy soils [38].

Table 2: Monthly Mean concentration of physical parameters from hand-dug wells

\begin{tabular}{|c|c|c|c|c|c|c|c|c|c|c|c|c|c|c|c|}
\hline Param & Units & Oct & Nov & Dec & Jan & Feb & Mar & Apr & May & Jun & Jul & Aug & Sep & $\begin{array}{l}\text { Mean } \\
\sum x / n\end{array}$ & $\begin{array}{l}\text { Max } \\
\text { limit }\end{array}$ \\
\hline $\begin{array}{l}\text { Odor } \\
\text { Col } \\
\text { Taste }\end{array}$ & TCU & $\begin{array}{l}\text { Acpt } \\
\text { CL } \\
\text { TL }\end{array}$ & $\begin{array}{c}\text { Acpt } \\
\text { CL } \\
\text { TL }\end{array}$ & $\begin{array}{c}\text { Acpt } \\
\text { CL } \\
\text { TL }\end{array}$ & $\begin{array}{l}\text { Acpt } \\
\text { CL } \\
\text { TL }\end{array}$ & $\begin{array}{c}\text { Acpt } \\
\text { CL } \\
\text { TL }\end{array}$ & $\begin{array}{c}\text { Acpt } \\
\mathrm{CL} \\
\mathrm{TL}\end{array}$ & $\begin{array}{c}\text { Acpt } \\
\text { CL } \\
\text { TL }\end{array}$ & $\begin{array}{c}\text { Acpt } \\
\text { CL } \\
\text { TL }\end{array}$ & $\begin{array}{c}\text { Acpt } \\
\text { CL } \\
\text { TL }\end{array}$ & $\begin{array}{c}\text { Acpt } \\
\text { CL } \\
T L\end{array}$ & $\begin{array}{c}\text { Acpt } \\
\text { CL } \\
\text { TL }\end{array}$ & $\begin{array}{c}\text { Acpt } \\
\mathrm{CL} \\
\mathrm{TL}\end{array}$ & & \\
\hline Tem & ${ }^{\circ} \mathrm{C}$ & 29 & 30.1 & 29.3 & 29.4 & 30 & 29.4 & 30.4 & 29.5 & 29.8 & 29.3 & 29.4 & 30.2 & 29.7 & 25.0 \\
\hline Turb & NTU & 2.1 & 2.2 & 1.8 & 1.6 & 1.63 & 1.8 & 1.9 & 2.0 & 2.0 & 2.0 & 2.2 & 1.9 & 1.9 & 5 \\
\hline TDS & $\mathrm{Mg} / \mathrm{l}$ & 136.7 & 128.3 & 113.7 & 106.3 & 102.7 & 99.7 & 112.7 & 111.0 & 123.0 & 137.7 & 153.7 & 144.7 & 122.5 & 600 \\
\hline $\begin{array}{l}\text { Amb } \\
\text { Temp }\end{array}$ & ${ }^{\circ} \mathrm{C}$ & $x$ & $x$ & $x$ & $x$ & $x$ & $x$ & 29.8 & 29.5 & 30.5 & 31.3 & 30.0 & 29.0 & 30 & 25 \\
\hline
\end{tabular}

${ }^{*}$ Acpt $=$ Acceptable $\quad{ }^{*} \mathrm{CL}=$ Colourless $\quad * \mathrm{TL}=$ Tasteless

${ }^{*}$ Ambient Temp $\left({ }^{\circ} \mathrm{C}\right)=$ was not taken for the first six months from October 2010 to march 2011

Table 3: Monthly Mean concentration of physical parameters from boreholes

\begin{tabular}{|c|c|c|c|c|c|c|c|c|c|c|c|c|c|c|c|}
\hline Par & Units & Oct & Nov & Dec & Jan & Feb & Mar & Apr & May & Jun & Jul & Aug & Sep & $\begin{array}{l}\text { Mean } \\
\sum x / n\end{array}$ & $\begin{array}{l}\text { Max } \\
\text { limit }\end{array}$ \\
\hline $\begin{array}{l}\text { Odor } \\
\text { Col } \\
\text { Taste }\end{array}$ & TCU & $\begin{array}{c}\text { Acpt } \\
\text { CL } \\
\text { TL }\end{array}$ & $\begin{array}{c}\text { Acpt } \\
\text { CL } \\
\text { TL }\end{array}$ & $\begin{array}{c}\text { Acpt } \\
\text { CL } \\
T L\end{array}$ & $\begin{array}{l}\text { Acpt } \\
\mathrm{CL} \\
\mathrm{TL}\end{array}$ & $\begin{array}{c}\text { Acpt } \\
\text { CL } \\
\text { TL }\end{array}$ & $\begin{array}{c}\text { Acpt } \\
\text { CL } \\
\text { TL }\end{array}$ & $\begin{array}{l}\text { Acpt } \\
C L \\
T L\end{array}$ & $\begin{array}{c}\text { Acpt } \\
\text { CL } \\
\text { TL }\end{array}$ & $\begin{array}{c}\text { Acpt } \\
\mathrm{CL} \\
\mathrm{TL}\end{array}$ & $\begin{array}{l}\text { Acpt } \\
\text { CL } \\
\text { TL }\end{array}$ & $\begin{array}{c}\text { Acpt } \\
\text { CL } \\
\text { TL }\end{array}$ & $\begin{array}{c}\text { Acpt } \\
\mathrm{CL} \\
\mathrm{TL}\end{array}$ & & \\
\hline Tem & ${ }^{\circ} \mathrm{C}$ & 29.1 & 30.0 & 29.3 & 29.4 & 30.0 & 30.1 & 30.3 & 30.0 & 29.7 & 29.1 & 28.6 & 30.4 & 29.7 & 25.0 \\
\hline Turb & NTU & 1.2 & 1.1 & 1.0 & 0.8 & 0.8 & 0.7 & 0.9 & 0.8 & 0.9 & 0.9 & 1.0 & 0.9 & 0.9 & 5 \\
\hline TDS & $\mathrm{Mg} / \mathrm{l}$ & 135.2 & 128.3 & 118.7 & 112.0 & 106.0 & 108 & 115 & 106 & 135 & 138 & 142 & 141 & 123.8 & 600 \\
\hline Amb Temp & ${ }^{\circ} \mathrm{C}$ & $x$ & $x$ & $x$ & $x$ & $x$ & $x$ & 29.8 & 29,5 & 30.5 & 31.3 & 30.0 & 29.0 & 30.0 & 25 \\
\hline
\end{tabular}


${ }^{*}$ Ambient Temp $\left({ }^{\circ} \mathrm{C}\right)=$ was not taken for the first six months from October 2010 to March 2011

So water contained and transmitted through the formation would be clear with low turbidity. The TDS for HDW and for BH had monthly mean results of $122.5 \mathrm{mg} / \mathrm{l}$ (Table 2) and $123.8 \mathrm{mg} / \mathrm{l}$ (Table 3) respectively. The results for both HDW and BH followed similar trend TDS obtained in this study had mean concentration of 125.1 $\mathrm{mg} / \mathrm{l}$, which falls far below the maximum limit of 600 $\mathrm{mg} / \mathrm{l}$ by WHO [26] and $500 \mathrm{mg} / \mathrm{l}$ by NIS/SON/ NAFDAC[27]. Excess TDS in water affect taste which may become unacceptable if it exceeds $600 \mathrm{mg} / \mathrm{l}$ [28]. This also could explain the reason why the water from the groundwater in the town had no problem of taste.

\subsection{Chemical Parameters}

The monthly mean concentrations of the chemical parameters of water from HDW are presented in Table 4, and those from $\mathrm{BH}$ are presented in Table 5. Both tables contain mean concentrations of the parameters for the one year of study and recommended maximum for the different parameters in drinking water.

The monthly mean pH for HDW ranged from 6.6 to 7.5 (Table 4), while that for BH ranged from 7.0 to 7.6 (Table
5). These indicate that the groundwater from HDW and $\mathrm{BH}$ are within the acceptable range of6.5 to 8.5 for drinking water (WHO, 2012). Ph of samples from HDW and $\mathrm{BH}$ are all within the permissible limit for drinking water. $\mathrm{pH}$ from $\mathrm{BH}$ and from HDW were similar and generally the groundwater of the study area was more alkaline than acidic. There were no signs of seasonal variation

Almost all other chemical parameters $(\mathrm{Cl}, \mathrm{Cu}, \mathrm{Pb}, \mathrm{Zn}, \mathrm{Cd}$, $\mathrm{NO}_{3}, \mathrm{TH}, \mathrm{TA}$ and conductivity for both HDW and $\mathrm{BH}$ were below the recommended maximum limits for the different parameters (Tables 4 and 5).The concentrations of chloride from boreholes are higher than those from the hand dug wells. $\mathrm{Cl}$ results vary during the study period for both HDW and $\mathrm{BH}$, but no trend could be established. Iron and fluoride were found to be above the recommended maximum limits of $0.3 \mathrm{mg} / \mathrm{l}$ and $1.5 \mathrm{mg} / \mathrm{l}$ respectively (Table 5 ). None of the parameters showed any significant variation throughout the year.

Table 4: Monthly Mean concentration of chemical parameters from hand-dug wells

\begin{tabular}{|c|c|c|c|c|c|c|c|c|c|c|c|c|c|c|c|}
\hline Par & Units & Oct & Nov & $\mathrm{Dec}$ & Jan & Feb & Mar & Apr & May & Jun & Jul & Aug & Sep & $\begin{array}{c}\text { Mean } \\
\sum x / n\end{array}$ & $\begin{array}{l}\text { Max } \\
\text { limits }\end{array}$ \\
\hline $\mathrm{pH}$ & $\mathrm{mg} / \mathrm{l}$ & 7.3 & 7.3 & 7.5 & 7.2 & 7.2 & 7.2 & 7.4 & 6.8 & 6.6 & 7.0 & 7.3 & 7.4 & 7,2 & $6.5-8.5$ \\
\hline $\mathrm{C} \overline{\bar{\Gamma}}$ & $\mathrm{mg} / \mathrm{l}$ & 56.4 & 49.5 & 49.7 & 48.2 & 48.2 & 47.4 & 52.4 & 43.4 & 47.3 & 54.1 & 60.0 & 70.0 & 48.6 & 250 \\
\hline $\mathrm{Fe}$ & $\mathrm{mg} / \mathrm{l}$ & 1.2 & 0.8 & 0.8 & 0.8 & 0.8 & 0.9 & 0.9 & 0.9 & 0.9 & 0.9 & 1.1 & 1.0 & 0.9 & 0.3 \\
\hline $\mathrm{Cu}$ & $\mathrm{mg} / \mathrm{l}$ & 0.07 & 0.09 & 0.39 & 0.04 & 0.04 & 0.03 & 0.05 & 0.04 & 0.05 & 0.06 & 0.07 & 0.07 & 0.05 & 1.0 \\
\hline $\mathrm{Pb}$ & $\mathrm{mg} / \mathrm{l}$ & ${ }^{*} \mathrm{BDL}$ & BDL & BDL & BDL & BDL & BDL & BDL & BDL & BDL & BDL & BDL & BDL & BDL & 0.01 \\
\hline $\mathrm{Zn}$ & $\mathrm{mg} / \mathrm{l}$ & 0.08 & 0.07 & 0.06 & 0.05 & 0.05 & 0.04 & 0.03 & 0.03 & 0.04 & 0.05 & 0.07 & 0.08 & 0.05 & 4.0 \\
\hline $\mathrm{F}^{-}$ & $\mathrm{mg} / \mathrm{l}$ & 2.1 & 2.1 & 2.0 & 2.0 & 2.0 & 1.8 & 1.8 & 1.7 & 1.7 & 1.8 & 1.8 & 1.6 & 1.9 & 1.5 \\
\hline $\mathrm{Cd}$ & $\mu \mathrm{s} / \mathrm{cm}$ & BDL & BDL & BDL & BDL & BDL & BDL & BDL & BDL & BDL & BDL & BDL & BDL & BDL & 0.003 \\
\hline $\mathrm{NO}_{3}{ }^{-}$ & $\mathrm{mg} / \mathrm{l}$ & 0.2 & 0.2 & 0.2 & 0.1 & 0.1 & 0.1 & 0.1 & 0.1 & 0.1 & 0.2 & 0.2 & 0.2 & 0.2 & 45 \\
\hline $\mathrm{TH}$ & $\mathrm{mg} / \mathrm{l}$ & 140 & 133 & 131 & 123.0 & 121.0 & 117.3 & 114.0 & 116.0 & 121.0 & 124.0 & 138.1 & 148.0 & 128 & 150 \\
\hline TA & $\mathrm{mg} / \mathrm{l}$ & ${ }^{*} X$ & $x$ & $x$ & $x$ & $x$ & $x$ & 145.3 & 171.0 & 187.0 & 199.3 & 138.1 & 148 & 164.8 & 200 \\
\hline Cond & $\mu \mathrm{s} / \mathrm{cm}$ & $x$ & $x$ & $x$ & $x$ & $x$ & $x$ & 226.0 & 231.7 & 273.0 & 306,0 & 302.0 & 302.0 & 273.5 & 1000 \\
\hline
\end{tabular}

Table 5: Monthly Mean concentration of chemical parameters from boreholes

\begin{tabular}{|c|c|c|c|c|c|c|c|c|c|c|c|c|c|c|c|}
\hline Par & Units & Oct & Nov & Dec & Jan & Feb & Mar & Apr & May & Jun & Jul & Aug & Sep & $\begin{array}{l}\text { Mean } \\
\sum x / n\end{array}$ & $\begin{array}{c}\text { Max } \\
\text { limits }\end{array}$ \\
\hline $\mathrm{pH}$ & $\mathrm{mg} / \mathrm{l}$ & 7.1 & 7.2 & 7.1 & 7.0 & 7.1 & 7.0 & 7.3 & 7.3 & 7.0 & 7.4 & 7.6 & 7.3 & 7.2 & $6.5-8.5$ \\
\hline $\mathrm{C} \overline{\bar{F}}$ & $\mathrm{mg} / \mathrm{l}$ & 56.9 & 60 & 62.2 & 58 & 61.9 & 70 & 73 & 65.5 & 64.2 & 76 & 86.2 & 81.5 & 68 & 250 \\
\hline $\mathrm{Fe}$ & $\mathrm{mg} / \mathrm{l}$ & 0.6 & 0.4 & 0.4 & 0.5 & 0.5 & 0.5 & 0.5 & 0.6 & 0.6 & 0.8 & 0.9 & 0.9 & 0.7 & 0.3 \\
\hline $\mathrm{Cu}$ & $\mathrm{mg} / \mathrm{l}$ & 0.06 & 0.09 & 0.05 & 0.06 & 0.06 & 0.06 & 0.07 & 0.06 & 0.7 & 0.9 & 0.9 & 0.9 & 0.33 & 1.0 \\
\hline $\mathrm{Pb}$ & $\mathrm{mg} / \mathrm{l}$ & 0 & 0 & 0 & 0 & 0 & 0 & 0 & 0 & 0 & 0 & 0 & 0 & 0 & 0.01 \\
\hline $\mathrm{Zn}$ & $\mathrm{mg} / \mathrm{l}$ & 0.1 & 0.07 & 0.07 & 0.06 & 0.06 & 0.05 & 0.05 & 0.06 & 0.06 & 0.09 & 0.1 & 0.09 & 0.06 & 4.0 \\
\hline $\mathrm{F}^{-}$ & $\mathrm{mg} / \mathrm{l}$ & 1.6 & 1.5 & 1.5 & 1.5 & 1.6 & 1.6 & 1.6 & 1.6 & 1.6 & 1.6 & 1.7 & 1.7 & 1.6 & 1.5 \\
\hline $\mathrm{Cd}$ & $\mu \mathrm{s} / \mathrm{cm}$ & BDL & BDL & $\mathrm{BDL}$ & BDL & $\mathrm{BDL}$ & BDL & $\mathrm{BDL}$ & BDL & $\mathrm{BDL}$ & $\mathrm{BDL}$ & $\mathrm{BDL}$ & $\mathrm{BDL}$ & $\mathrm{BDL}$ & 0.003 \\
\hline $\mathrm{NO}_{3}^{-}$ & $\mathrm{mg} / \mathrm{l}$ & 0.2 & 0.2 & 0.2 & 0.1 & 0.1 & 0.1 & 0.1 & 0.1 & 0.1 & 0.2 & 0.3 & 0.2 & 0.21 & 45 \\
\hline TH & $\mathrm{mg} / \mathrm{l}$ & 161 & 153.2 & 149 & 146 & 147.4 & 150 & 149 & 130 & 137 & 140 & 177.3 & 160.2 & 139.2 & 150 \\
\hline $\mathrm{TA}$ & $\mathrm{mg} / \mathrm{l}$ & $x$ & $\mathrm{x}$ & $x$ & $x$ & $x$ & $\mathrm{x}$ & 96 & 119.3 & 132 & 138.3 & 145 & 145 & 129.3 & 200 \\
\hline Cond & $\mu \mathrm{s} / \mathrm{cm}$ & $x$ & $x$ & $x$ & $x$ & $x$ & $x$ & 264.4 & 262.2 & 273 & 284.3 & 280 & 295 & 276.5 & 1000 \\
\hline
\end{tabular}


This is different from the findings Adekunle and others [10], who found out that the parameters determined were highest during the rainy season in Southwest Nigeria . That may be as a result of differences in rainfall patterns, other climatic factors and geologic formations. Iron showed a mean concentration values of $0.90 \mathrm{mg} / \mathrm{l}$ for HDW and $0.7 \mathrm{mg} / \mathrm{l}$ for BH.. These values are far above the recommended maximum limit of $0.3 \mathrm{mg} / \mathrm{l}$, the trend of variation is as shown graphically in Fig 3, for both HDW and BH. Both samples from hand dug wells and boreholes therefore showed high iron content, but Iron content in hand dug wells were higher than those found in boreholes. The high values for iron could be attributed to the presence of minerals usually associated with shale, crystalline basement rocks, sandstones and iron stones which are present in Kaltungo area [29] and which are sources of Iron. Minerals like mica, amphiboles, and hornblende are identified with rocks of crystalline basement rocks [30] which are also sources of Iron. Iron in hand dug wells being higher than those found in boreholes could be due to Iron releases by decomposition from the rocky mountains which surrounds Kaltungo town and during the rainy season washed and transported by running water into the wells by seepage because most of them are shallow wells between the depth of 5-15 $\mathrm{m}$ as against boreholes which are deep within the range of 25- $200 \mathrm{~m}$ [31]. High levels of Iron in water may produce bad odour and taste, which may affect the portability of water [32]. This effect was however not noticed in this study. The other effect is that high concentration of iron in water alters the appearance of the water when it stands for some time. Iron deposit also cause staining of plumbing fixtures and in laundry [33].

The mean monthly fluoride concentration was $1.9 \mathrm{mg} / \mathrm{l}$ for HDW (Table 4) and $1.60 \mathrm{mg} / \mathrm{I}$ for BH (Table 5). Fig 3 shows how the results varied throughout the year of study and also shows that fluoride concentration in Kaltungo groundwater was too high for most of the year. It was above the stipulated maximum limit of $1.5 \mathrm{mg} / \mathrm{l}$ recommended for drinking water by WHO [25] and
NIS/SON/NAFDAC [26]. Results for HDW were higher than those for BH throughout the year of study. Granite rocks of these areas are reported to contain minerals like fluomica, fluorapatite, amphiboles, pyrexes, present in Kaltungo area which are good sources of fluorine [29]. Another explanation for the fluoride- rich waters could be the weathering of the fluoride-bearing minerals in rocks and soils in the area. A borehole log recorded during drillings confirmed the presence of fluoride bearing mineral accessories in Kaltungo area [34]. Therefore, high fluoride concentration in HDW and $\mathrm{BH}$ could be due to basement complex, underlying the formation in the area.

Low levels of fluoride $(0.00-0.6) \mathrm{mg} / \mathrm{l}$, in drinking water can cause dental caries (tooth decay),levels between $0.7 \mathrm{mg} / \mathrm{l}-1.5 \mathrm{mg} / \mathrm{l}$ would prevent tooth decay [35], and high levels from above $1.5 \mathrm{mg} / \mathrm{l}$, in drinking water cause fluorosis (pains and tenderness of bones) and teeth mottling among the inhabitants, especially children of primary school age [36,37]. The above conditions can be prevalent among consumers of the water with high fluoride content. Therefore it can be said that, the mottling of teeth that children who grow up in Kaltungo town have is caused by high concentration of fluoride in the water they drink from hand dug wells and boreholes in the town

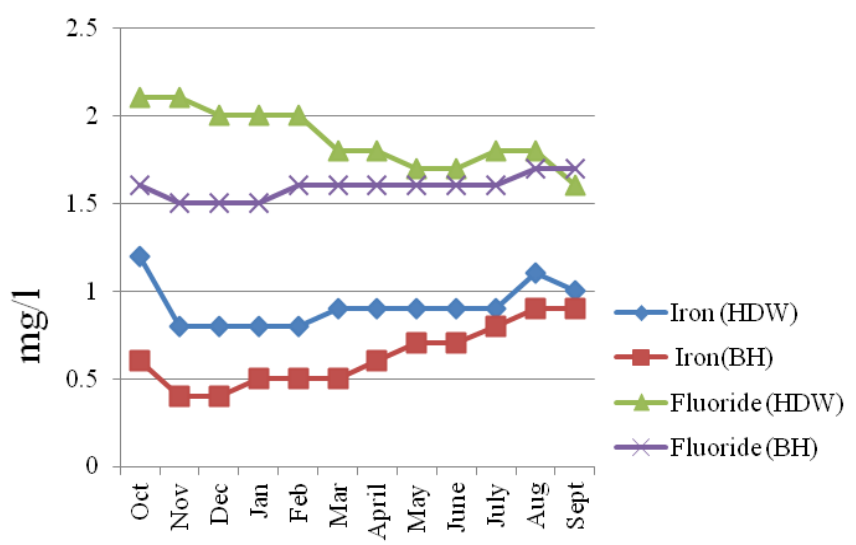

Fig 3: Iron and Fluoride concentrations in water samples from Hand dug wells (HDW) and Bore holes (BH).

Table 6: Treatment Results Using Alum, Bone Charcoal and Moringaoleifera Seeds (mg/l)

\begin{tabular}{c|c|rrrr|rrrr|rrrr}
\hline Rep & Untreated (UT) & \multicolumn{10}{|c}{ TREATMENTS } \\
\hline & & A5 & A10 & A15 & A20 & B5 & B10 & B15 & B20 & M5 & M10 & M15 & M20 \\
\hline 1 & 1.70 & 1.60 & 1.25 & 1.32 & 1.40 & 1.54 & 1.45 & 1.30 & 1.15 & 1.64 & 1.46 & 1.20 & 0.90 \\
2 & 1.68 & 1.59 & 1.27 & 1.35 & 1.44 & 1.52 & 1.40 & 1.32 & 1.18 & 1.63 & 1.43 & 1.25 & 1.02 \\
3 & 1.69 & 1.61 & 1.26 & 1.33 & 1.42 & 1.50 & 1.43 & 1.34 & 1.14 & 1.65 & 1.45 & 1.27 & 0.95 \\
Total & 5.07 & 4.80 & 3.78 & 4.00 & 4.26 & 4.56 & 4.28 & 3.96 & 3.47 & 4.92 & 4.34 & 3.72 & 2.87 \\
Mean & 1.69 & 1.60 & 1.26 & 1.33 & 1.42 & 1.52 & 1.43 & 1.32 & 1.16 & 1.64 & 1.45 & 1.24 & 0.96 \\
\hline
\end{tabular}

$\mathrm{A}=$ Alum at 5g, 10g, 15g and 20g per litre of water samples, B = Bone charcoal at 5g, 10g, 15g and 20g per litre of water samples, $\mathrm{M}=$ Moringa Oleifera at $5 \mathrm{~g}, 10 \mathrm{~g}, 15 \mathrm{~g}$ and $20 \mathrm{~g}$ per litre of water samples 


\subsection{Treatment of Water Samples}

The results for the treatments of water with alum, bone charcoal and moringaoleifera at different levels for the reduction of fluoride are presented in Table 6

At 5g/ litre, alum reduced the concentration in the three replications but all the results were still above the maximum limit of $1.5 \mathrm{mg} / \mathrm{l}$ of flouride. The use of $10 \mathrm{~g}$, $15 \mathrm{~g}$ and $20 \mathrm{~g}$ of alum per litre of water samples gave satisfactory results that were all below $1.5 \mathrm{mg} / \mathrm{l}$. Alum is generally used in water treatment for coagulation, forming flocs that are taken out of the water. From the results of this work, is it possible to investigate the chemical composition of the flocs that are removed from water after the addition of alum. The results for bone charcoal and moringaoliefera were similar. The $5 \mathrm{~g} / \mathrm{l}$ for both of them had results that were still higher than the maximum limit of $1.5 \mathrm{mg} / \mathrm{l}$. But from dosages of $10 \mathrm{~g} / \mathrm{l}$, $15 \mathrm{~g} / \mathrm{l}$ and $20 \mathrm{~g} / \mathrm{l}$ all the results were sufficiently below $1.5 \mathrm{mg} / \mathrm{l}$. So all the tests using Alum, Bone charcoal and moringaoleifera as treatments for fluoride removal proved effective with a dosage of $10 \mathrm{~g} / \mathrm{l}$ or more of treatment material to water samples in the reduction of fluoride concentration in the water sample. But while alum had no trend, for bone charcoal and moringaoliefera, the higher the dosage, the higher the removal of fluoride.

\section{CONCLUSION}

From this study groundwater quality assessments of Kaltungo were carried out for a period of one year. The following findings/ conclusion were made.

(i) Physical characteristics of odour, colour, turbidity, total dissolved solids and taste were found to be within the acceptable recommended limits prescribed for human consumption. Temperature was found to be above the maximum limit of WHO guideline, but within the acceptable range set by Nigerian standards.

(ii) Most of the chemical characteristics varied in concentrations. $\mathrm{pH}$, chloride, $\mathrm{TH}$, copper, zinc, cadmium, nitrate were all found within the acceptable maximum limits for drinking water, except Iron and fluoride which, were far above the stipulated maximum limit for drinking water.

(iii) High concentration of Fluoride could have been the cause of teeth mottling among children while developing their teeth as they grow up in the town.

(iv) Alum, bone charcoal and moringaoleifera were found to be effective in removal of fluoride from water. (v) It is recommended that efforts should be made to treat Kaltungo ground water for fluoride removal with local and available material of bone charcoal and moringaoliefera before drinking especially by children of teething age.

(vi) Attempts can also be made to treat water to reduce Iron which is also above the recommended limit of $0.3 \mathrm{mg} / \mathrm{l}$.

\section{REFERENCES}

[1] James, M. S., Lee, C. B. R. Theodore, C. C, The Drinking Water Dictionary. Mcgraw-Hill N/Y USA 2001.

[2] Gedzelman, S.D. Student (DVD) “Water Cycle” , Redmon, WA: Microsoft Corporation. 2009.

[3] Ward, R. C. \& Robinson, M. Principles of Hydrology (3 ${ }^{\text {rd }}$ Edition.).McGraw-Hill Co. London. 1990.

[4] Moro, M.O. and S.B. Onoja, Utilization of Shallow Aquifers for small- scale Irrigation: A case of AgatuLocal Government Area of Benue State, Nigerian Journal of Technology 25(2): 59-65 ISSN 1115 -8443, Nigeria 2006.

[5] Ojo, I.0, Otieno, F. A. 0, andOchieng, G. M. Groundwater: Characteristics, qualities, pollution and treatment :An overview. Int. Journal of Water Resources and Environ Engineering. Vol. 4(6) pp 162-170, 2012.

[6] Raven, H.P., Linda R. B., George B. J. Environment, (2nd edition). Emily Barrosepubl. USA. 1998.

[7] Cronin, A.A, Hoadley, A.W, Gibson, J, Breslin, N, Kommou, F.K, Haldin L, and Pedley S. Journal of Water and Health 05(3) pp 441-454, 2007.

[8] Tebbut, T.H.Y Principles of Water Quality Control, ( $2^{\text {nd }}$ edition). Pergamon, Oxford. 1990.

[9] Niel, L. P., Laura M.B., and Scott, K. A. In Bartolio, J. R., and Cole, J.C. How Groundwater Chemistry helps us Understand the Aquifer. U.S. Geological Survey Circular 1222, Reston, Virginia. P. 93. 2003.

[10] Adekunle, I. M. Adetunji, M.T. Gbadebo, A. M. and Banjoke, O. B. "Assessment of Groundwater Quality in a Typical Settlement in South Western Nigeria". Int J. Environ Res Public Health 4(4) 307-318. 2007.

[11] Adakole, J. A. Adegbola, F.F. and Luka, A. C. "Assessment of Water Quality from Hand Dug Wells in Samaru,11 Zaria" AQUA Mundi 18:155-160. 2010.

[12] MacDonald, A. M., Davis J., Dochartaigh B. E., Simple Methods of Assessing Groundwater Resources in Low Permeability Areas of Africa, Report CR/01/168N, 20 BGS, Keyworth. 2001. 
[13] Yeung, C. A. "A systematic review of the efficacy and safety of fluoridation" . Evid Based Dent. 2008; 9(2):39-43 National Health and Medical Research Council (Australia). NHMRC, 2007.

[14] A1varez J. A, Rezende, K. M. P. C., Marocho, S. M. S., Alves, F. B. T. Celiberti, P., Ciamponi. A. L. "Dental Fluorosis: Exposure, Prevention and Management" . Med Oral Patol Oral Cir Bucal. 2009;14(2):E103-7. PMID 19179949. 2009.

[15] Na1iona1 Population Commission (NPC), Population Figures For Kaltungo LGA, Gombe State. 2006.

[16] Umaru, A. F. M and Schoeick K. "Hydro geological investigation of the aquifers of Bauchi area" . Journal of mining and Geology. No, 26 (1), 45-53. 1992.

[17] Shemang, E. M. (Jr) and Umaru A. F. M “ Geophysical investigation for groundwater in the area around Bauchi town1. Journal of mining and Geology. 30 (1), 81-86, 1994.

[18] Oyawoye, M. 0: The basement complex of Nigeria in Africa Geology. University of Ibadan (ed). 1970.

[19] McCurray, P. The geology of the Precambrian to lower palaeogoic rocks of Northern Nigeria. $A$ Review, In geology of Nigeria, Kogbe(ed). 15-39. 1976.

[20] Offodile, M. E: Approach to groundwater study and development in Nigeria. Mecon Services Ltd, Jos. 7683. 1992.

[21] Ademoroti, C.M.A Standard Method for Water Effluents Analysis. Foludex press Ltd, Ibadan. Pp 15-184. 1996.

[22] American Public Health Association, American Water Works Association and Water Pollution Control Federation (APHA/AWWA/WPCF), Standard Methods for Examination of Water and Wastewater.15 ${ }^{\text {th }}$ Ed. 1134p. 1980.

[23] Ndabigengesere, A. and Narasiah, K. S. "Quality of water treated by coagulation using moringaoleifera seeds" . Water Research 32(3) 781-791

[24] Medellin-Castillo, N A.; R. Leyva-Ramos; R. OcampoPerez, ;R.F. Garcia de la Cruz; A. Aragon-Piña; J.M. Martinez-Rosales; R. M. Guerrero-Coronado; and L. Fuentes-Rubio."Adsorption of Fluoride from Water Solution on Bone Char". Industrial \& Engineering Chemistry Research 46 (26): 9205-9212. 2007.
[25] www.jnblabs.com What is the purpose of adding alum to water in a water treatment plant? 2009.

[26] World Health Organization. Guidelines for Drinking

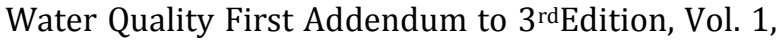
WHO, Geneva. 2012.

[27] Nigerian Industrial Standard (NIS); Standard Organization of Nigeria (SON) and National Food and Drug Administration Control (NAFDAC),Nigerian Standard for Drinking Water Quality, NIS 554: Wuse Zone 7, Abuja, Nigeria. 2007.

[28] Egeneonu, U.U and Osuzu C. I. U. "Physicochemical Analysis of the River Niger at Onitsha Bank, Nigeria" . Journal of chemical society of Nigeria; 30(2): 197-203. 2005.

[29] Carter, J. D. Barber W. and Tait E. A.. The geology of parts of Adamawa, Bauchi and Borno Provinces in North-Eastern Nigeria. Bull geological survey Nigeria, No.30, 1963.

[30] Environmental Protection Agency New Guidelines on Drinking Water Quality, $1^{\text {st }}$ Ed. U.S. Working Group, Advisory Edition. U.S, 2012 .

[31] Driscall, F.G. (Editor). Groundwater and Wells; Filtration Systems .published by John Inc, St. Paul, Minesota 2 Pp. 86-89. 1986.

[32] Agunwamba, J. C Water Engineering Systems, Revised Edition. Publ. by De- Adroit Innovation, Enugu. 2008.

[33] Shiklemanov, I. A,. "Appraisal and Assessment of World Water Resources". Journal of Water International; 25 (1): 11-15. 2000.

[34] American Water Works Association (AWWA). Water Quality and Treatment, McGraw Hill, New York, Pp. 45-60. 2007.

[35] Bauchi State Water Board (BSWB) Construction of Productive Boreholes. Conred Nigeria Ltd, No, 28, Pp. 452-459. 1983.

[36] Park, K. Principles of Preventive and Social Medicine, $18^{\text {th }}$ Ed. Banarsids BhanoJabalpur, India. 2005.

[37] Nanyaro J.T: Aswathanrayanu U; and Mungure, "A geochemical model for the abnormal 1984. Fluoride concentration in water in parts of Northern Tanzania” . Journal of African Earth Science 2 (2), 129-140.

[38] McDongh, M.; John, C and Michael. P. Systematic Review of Water Fluoridation. British Medical Journal321 (7265): 855-859. 2004. 